\section{Penerapan Akuntabilitas Dan Maslahat Dalam Perspektif Hukum Wakaf}

Muhammad Zuhirsyan' ${ }^{1}$ (Penulis_1) zuhirsyan12@gmail.com.

Nurlinda (Penulis_2)

\section{Abstract}

This study aims to find out the application of accountability and benefits in waqf law and also to find out the urgency of recording waqf in the perspective of Islamic law and accountability in disclosure. The object of the research is the implementation of waqf in Medan City community. This is a descriptive qualitative research. The method of collecting the data in research uses library research and interviews with several related parties. The sampling technique uses random sampling. The type of data used in this study is secondary primary data. The data analysis used is descriptive by using literature studies in the form of muamalah figh books including the DSN-MUI fatwa.

The results showed that Waqf is one of the legal actions that have been determined by rules, harmony and conditions, both in the perspective of classical Jurisprudence and legislation in Indonesia. The application of waqf law as a legal act in the perspective of benefit and accountability can be realized by recording waqf up to reporting the development of waqf management to the Indonesian Waqf Agency (IWA) or it can be conveyed directly to the public.

Keywords: Waqf, Accountability, Benefits

\section{Abstrak}

Penelitian ini bertujuan guna melihat penerapan akuntabilitas dan maslahat dalam hukum wakaf dan menemukan urgensi pencatatan wakaf dalam perspektif hukum Islam dan akuntabilitas dalam pengungkapan. Adapun objek penelitian adalah pelaksanaan wakaf pada masyarakat Kota Medan. Jenis penelitian ini adalah deskriptif kualitatif. Metode pengumpulan data
Pada penelitian menggunakan library research dan wawancara kepada beberapa pihak terkait. Teknik pengambilan sampel menggunakan random samping. Jenis data yang dipakai dalam penelitian ini merupakan data primer sekunder. Analisis data yang dipakai menggunakan deskriptif dengan menggunakan studi literatur yang berupa buku-buku fikih muamalah termasuk juga fatwa DSN-MUI.

Hasil penelitian menunjukkan Wakaf merupakan salah satu perbuatan hukum yang telah ditentukan aturan, rukun dan syaratnya, baik dalam perspektif fikih klasik maupun peraturan perundang-undangan di Indonesia. Penerapan perbuatan hukum wakaf sebagai suatu perbuatan hukum dalam perspektif kemaslahatan dan akuntabilitas dapat diwujudkan dengan melakukan pencatatan wakaf hingga pelaporan perkembangan pengelolaan wakaf kepada lembaga Badan Wakaf Indonesia (BWI) atau langsung kepada publik.

Kata Kunci : wakaf, akuntabilitas, maslahat

\section{Pendahuluan}

\section{A. Latar Belakang}

Salah satu perbuatan hukum yang banyak dilakukan, dilihat dan dirasakan masyarakat muslim Indonesia adalah wakaf. Banyak ditemukan wakaf yang dilakukan kaum muslim baik yang bersifat personal maupun kelompok yang masih ada hingga saat ini dan memberikan manfaat bagi masyarakat sekitar. Namun di sisi lain, tidak sedikit aset wakaf yang menuai permasalahan bahkan perselisihan baik antara keluarga pewakif dengan nazir maupun lainnya.

Sebagai salah satu bidang keilmuan, ilmu ushul fikih harus terus dikembangkan dan dilestarikan sebagai kunci menemukan berbagai kemaslahatan yang seiring perubahan waktu

\footnotetext{
${ }^{1}$ Dosen Politeknik Negeri Medan
} 
Media Komunikasi dan Informasi Hukum dan Masyarakat

dan perkembangan teknologi semakin memiliki ruang lingkup yang besar dan luas.

Jika dilihat perspektif hukum Islam, sisi kemaslahatan merupakan sesuatu yang sangat urgen untuk diterapkan, karena memang tujuan pemberlakuan hukum Islam itu sendiri adalah untuk mencapai kemaslahatan di dunia dan akhirat.

Dalam bidang akuntansi, akuntabilitas juga merupakan sesuatu yang sangat urgen diterapkan dalam berbagai bidang dan di berbagai lapisan masyarakat. Tentunya hal ini bertujuan agar menjaga munculnya dampak negatif yang tidak dikehendaki.

Untuk mengindari hal-hal yang tidak diinginkan dan demi mewujudkan kemaslahatan umum yang ada di dalam pelaksanaan wakaf, maka sangat perlu melakukan pengkajian mendalam terhadap problematika wakaf dalam sudut hukum Islam melalui penguatan melalui akuntabilitas dan maslahat.

Problematika perkawafan di Indonesia saat ini adalah masih banyaknya harta wakaf yang belum dicatatkan di Kantor Urusan Agama (KUA) setempat. Pelaksanaan wakaf oleh sebagian umat Islam hanya sekedar dilakukan secara lisan dan tidak di hadapan Pejabat Pembuatan Akta Ikrar Wakaf (PPAIW), sehingga wakaf itu tidak ada dokumentasinya di KUA. Begitu juga, masih banyak harta wakaf yang belum didaftarkan di Badan Pertanahan Nasional (BPN) kabupaten/kota setempat sehingga masih banyak harta wakaf yang belum bersetifikat wakaf. Al ini disebabkan karena kurangnya kesadaran hukum masyarakat untuk mengurus pendaftaran harta wakaf di BPN, maupun rumitnya prosedur yang dilalui sebagian nazhir wakaf di beberapa BPN kabupaten/kota dalam proses sertifikasi harta wakaf tersebut. $^{2}$

Namun, tampaknya di masa sekarang urgensi yang harus menjadi perhatian adalah pengelolaan wakaf yang lebih profesional melalui penegasan pencatatan dan pelaporan, sehingga menjadikan perbuatan wakaf lebih dapat lebih kuat berdasarkan legalitas wakaf di mata hukum baik itu hukum Islam maupun hukum konvensional.

Untuk itu, penelitian ini sangat menarik untuk dilakukan, dengan judul pembahasan : Penerapan Akuntabilitas dan Maslahat Dalam Perspektif Hukum Wakaf

\section{B. Rumusan Masalah}

Berdasarkan latar belakang di atas maka dapat ditarik sebuah permasalahan sebagai berikut :

1. Bagaimana kedudukan wakaf sebagai suatu perbuatan hukum dalam Islam?.

2. Bagaimana penerapan wakaf sebagai suatu perbuatan hukum dalam pesepektif kemaslahatan dan akuntabilitas.

\section{Metode Penelitian}

Penelitian ini dilaksanakan di Kota Medan sebagai ibukota Provinsi Sumatera Utara. Di Kota ini banyak ditemukan tanah wakaf.

Penelitian ini menggunakan parameter kajian hukum Islam (hukum bisnis syariah) dan sudut akuntabilitas. Dimana, penerapan wakaf sebagai perbuatan hukum dianalisis dan diukur dengan studi literatur dan kepustaakaan sumber hukum Islam seperti Alquran, Hadis, dan ljtihad para ulama melalui fatwa maupun lainnya. Di samping itu akan dilakukan beberapa

${ }^{2}$ Rozalinda, Manajemen Wakaf Produktif, RajaGrafindo Persada, Jakarta, 2016, hal. 57 
Media Komunikasi dan Informasi Hukum dan Masyarakat

wawancara ke beberapa pakar dalam bidang wakaf.

Penelitian merupakan klasifikasi terhadap berbagai persoalan yang masih belum jelas. Tujuan langsung dari studi ini adalah untuk mengembangkan hipotesis atau pertanyaan-pertanyaan untuk penelitian selanjutnya.

Fenomena permasalahan yang telah disampaikan diatas akan dicoba dijawab atau dicarikan solusinya melalui metode pendekatan yuridis empiris. Penggunaan pendekatan yuridis karena dalam membahas permasalahan penelitian ini nantinya akan menggunakan bahan-bahan hukum perspektif syariah dan akuntabilitas. Sementara Pendekatan empiris digunakan karena dalam penelitian ini dipakai data primer yang diperoleh peneliti dari kegiatan lapangan. Pendekatan yuridis empiris dalam penelitian yang akan dilakukan ini bermaksud bahwa analisis permasalahan akan dilakukan melaui cara mengkolaborasikan bahan-bahan hukum yang merupakan data sekunder dengan data primer yang diperoleh di lapangan yaitu tentang tema penelitian ini.

\section{Pembahasan}

\section{A. Kedudukan wakaf sebagai suatu perbuatan hukum}

Wakaf merupakan salah satu perbuatan hukum, oleh karena itu dalam pelaksanaannya harus diperhatikan mengenai syarat dan rukunnya. Dalam istilah fikih, perbuatan mukallaf disebut dengan mahkim fih.

Definisi mahkum fih, merujuk pada tindakan mukallaf yang berhubungan dengan hukum. ${ }^{3}$ Sebagaimana yang dikemukakan Wahbah Zuhaily di awal pembahasan tentang

${ }^{3}$ Wahab Khalaf, IImu Ushul Figh, Dar al-Kutub alIslamiyah, 2010, Jakarta, hal. 112 mahkum fih, penyebutkan mahkum fih adalah dikarenakan perbuatan merupakan sesuatu yang bersifat mahkum fih (dihukum/dinilai) dengan perintah atau larangan misalnya, dan disebut juga terkadang dengan mahkum bih karena perbuatan mukallaf digambarkan terkait dengan sesuatu yang diperintahkan atau yang dilarang. ${ }^{4}$

Mahkum fih yang terdapat dalam hukum taklifi selalu perbuatan yang mampu dilakukan mukallaf, baik yang wajib, haram, sunat, makruh maupun mubah. Sedangkan mahkum fih yang terdapat dalam hukum wadh'i adakala perbuatan mukallaf dan adakalanya bukan perbuatan mukallaf akan tetapi berkaitan dengan perbuatan mukallaf. Contohnya adalah tergelincirnya matahari yang menjadi sebab kewajiban shalat bagi mukallaf. Keterkaitan hukum wadh'i dengan perbuatan mukallaf adalah melalui perantaraan keterkaitan hukum taklifi dari sisi sebab, syarat maupun penghalang. ${ }^{5}$

Wakaf dari kata waqf yang secara bahasa merupakan masdar dari kata kerja waqafa asy-syai', yang artinya adalah sesuatu berhenti. Sama arti dengan kata habasa dan sabbala. Waqf telah menjadi kata serapa dalam bahasa Indonesia dengan istilah wakaf. $^{6}$ alThayyar (2009: 437)

Menurut Muhammad al-Syarbini alKhatib sebagaimana yang dikutip oleh Mardani, wakaf adalah penahanan harta yang memungkinkan untuk dimanfaatkan disertai dengan kekalnya zat benda dengan memutuskan (memotong) tasharuf (penggolongannya) dalam penjagaannya atau

${ }^{4}$ Wahbah Zuhaily, Ushul Figh al-Islamy Waadilatuhu, Jld. I, Darul Fikr, 2004, Damaskus, hal. 132

5 Ibid, hal. 133

${ }^{6}$ Abdullah al-Thayyar, Ensiklopedi Fiqh Muamalah, Maktabah al-Hanif, Yogyakarta, 2009, hal. 437 
Media Komunikasi dan Informasi Hukum dan Masyarakat

mushrif (pengelola) yang dibolehkan adanya. Dalam definisi lainnya, wakaf merupakan tindakan untuk 'menahan' harta yang dimungkinkan untuk dimanfaatkan tanpa 'menghabiskan' atau 'merusak' bendanya dan digunakan untuk kebaikan. Dalam definisi lainnya, wakaf adalah menahan harta yang mungkin diambil manfaatnya tanpa menghabiskan atau merusak bendanya dan digunakan untuk kebaikan. ${ }^{7}$

Dalam Kompilasi Hukum Islam, wakaf adalah perbuatan hukum seseorang atau kelompok orang atau badan hukum yang memisahkan sebagian dari benda miliknya dan melembagaannya untuk selama-lamanya guna kepentingan ibadah atau keperluan umum lainnya sesuai dengan ajaran Islam.

Menurut Peraturan Perundangundangan (PP) 28 Tahun 1977: Perbutan hukum seseorang atau badan hukum yang memisahkan sebagian dari harta kekayaannyayang berupa tanah milik dan melembagakannya untuk selama-lamanya untuk kepentingan peribadatan atau keperluan umum lainnya sesuai dengan ajaran Islam.

Dalam undang undang nomor 41 tahun 2004, wakaf di artikan dengan perbuatan hukum wakif (orang yang berwakaf) untuk memisahkan dan atau menyerahkan sebagian harta benda miliknya, untuk dimanfaatkan selamanya atau untuk jangka waktu tertentu sesuai dengan kepentingannya guna keperluan ibadah dan atau kesejahteraan umum menurut syariah.

Menurut UU Nomor 3 Tahun 2006: Perbuatan seseorang atau sekelompok orang (Wakif) untuk memisahkan dan/ atau menyerahkan sebagaian harta benda miliknya

7 Mardani, Aspek Hukum Lembaga Keuangan Syariah Di Indonesia. Prenamedia Group, Jakarta, 2015, hal. 277 untuk dimanfaatkan selamanya atau untuk jangka waktu tertentusesuai dengan kepentingannya guna keperluan ibadah dan/atau kesejahteraan umum menurut syari'ah. Wakaf tidak dijelaskan secara eksplisit dalam Alquran, namun demikian ada petunjuk umum tentang wakaf. Seperti firman Allah :

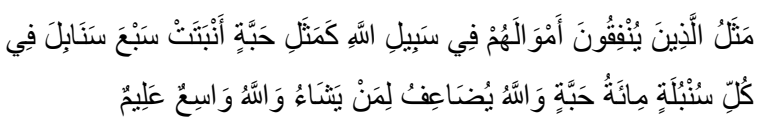
Perumpamaan (nafkah yang dikeluarkan oleh) orang-orang yang menafkahkan hartanya di jalan Allah adalah serupa dengan sebutir benih yang menumbuhkan tujuh bulir, pada tiap-tiap bulir seratus biji. Allah melipat gandakan (ganjaran) bagi siapa yang Dia kehendaki. Dan Allah Maha Luas (karunia-Nya) lagi Maha Mengetahui. (QS. Albaqarah: 261)

Pada ayat selanjutnya masih pada surat yang sama, Allah berfirman :

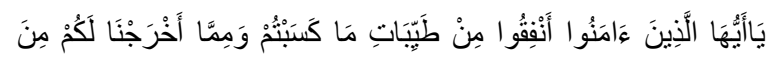

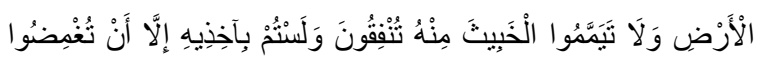

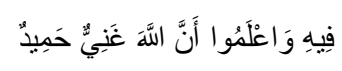

Hai orang-orang yang beriman, nafkahkanlah (di jalan allah) sebagian dari hasil usahamu yang baik-baik dan sebagian dari apa yang Kami keluarkan dari bumi untuk kamu. Dan janganlah kamu memilih yang buruk-buruk lalu kamu menafkahkan daripadanya, padahal kamu sendiri tidak mau mengambilnya melainkan dengan memincingkan mata terhadapnya. Dan ketahuilah, bahwa Allah Maha Kaya lagi Maha Terpuji. (QS. Al-Baqarah: 267)

Adapun dari hadits di antaranya adalah riwayat dari Ibnu Umar r.a, "Diiriwayatkan dari Ibnu Umar r.a. ia berkata, bahwa Umar mendapatkan sebidang tanah di Khaibar, lalu ia pergi kepada Rasilullah SAW seraya berkata: Saya mendapatkan bagian tanah yang belum 
Media Komunikasi dan Informasi Hukum dan Masyarakat

pernah saya dapatkan harta yang paling saya sayangi sebelumnya dari harta itu. Apakah yang akan Nabi peintahkan kepada saya? Rasulullah menjawab: Jika Engkau mau tahanlah dzat bendanya dan sedekahkan hasilnya. Kemudian Umar menyedekahkan dan (menyuruh)supaya tidak dijual, dihibahkan dan diwariskan sedangkan manfaat benda itu diberikan kepada fuqara', sanak kerabat, hamba sahaya, sabilillah tamu dan pelancong. Tidak ada dosa bagi yang mengurusi harta tersebut makan secara wajar atau memberi makan kepada temannya dengan tidak bermaksud memilikinya.

Berdasarkan sisi penunjukan wakaf, wakaf ini diklasifikasikan kepada dua, yaitu; ${ }^{8}$

a. Wakaf ahli atau wakaf dzurri, disebut dengan demikian karena disebut demikian karena wakaf ini ditujukan kepada orangorang tertentu, baik seorang atau lebih atau baik keluarga si wakif sendiri atau bukan.

b. Wakaf khairi, merupakan wakaf yang ditujukan untuk kepentingan 'agama' atau 'kemasyarakat' secara 'tegas'. Contoh untuk waqaf khairi seperti 'pembangungan masjid', 'sekolah', 'jembatan', 'rumah sakit' dan lainnya.

Sebagaimana yang dikemukakan Faisal Haq, ${ }^{9}$ wakaf merupakan salah satu perbuatan hukum, oleh karena itu dalam pelaksanaannya harus diperhatikan mengenai syarat dan rukunnya. Jumhur ulama menyatakan bahwa rukun wakaf ada 4 (empat) yakni:

a. Wakif, yakni individu yang menyerahkan hartanya sebagai waqaf.

b. Mauquf merupakan 'harta' yang diserahkan sebagai waqaf.

${ }^{8}$ Abdul Shomad, Hukum Islam Penormaan Prinsip Syariah Dalam Hukum Islam Indonesia. Kencana, Jakarta, 2010, hal. 372

${ }^{9}$ Faisal Haq, Hukum Perwakafan di Indonesia, RajaGrafindo Persada, Jakarta, 2017, hal. 6 c. Mauquf 'alaihi, merupakan niat atau tujuan/ individu yang bertanggungjawab dalam mengelola harta waqaf.

d. Sighat adalah sebuah pernyataan dari waqif bahwa waqif bahwa hartanya telah diwaqafkan.

Sedangkan rukun wakaf menurut Undang-Undang (UU) No. 41/2004, terdiri dari 6 (enam). Empat rukun seperti yang telah dikemukakan sebelumnya dan lalu ditambah lagi 2 (dua) yaitu:

1) Peruntukan harta benda wakaf.

2) Jangka waktu wakaf

Wakaf dinyatakan sah apabila telah terpenuhi rukun dan syaratnya. Adapun rukunnya adalah:

1) Waqif (orang yang berwakaf)

2) Mauquf bih (harta wakaf)

3) Mauquf 'alaih (tujuan wakaf)

4) Shighat (pernyataan atau ikrar waqif secara sukarela atas kemauan atau kehendak sendiri mewakafkan sebagian harta miliknya).

Sementara Syarat Wakaf adalah sebagai berikut;

1) Syarat Wakif berdasarakan Hukum Islam terdiri dari merdeka, berakal, sehat, dewasa, tidak berada di bawah pengampuan. Sedangkan syarat menurut UU No. 41/2004 bagi waqif perorangan terdiri dari dewasa, barakal sehat, tidak terhalang melakukan perbuatan hukum, dan pemilik sah harta wakaf. Sedangkan bagi waqif organisasi, undang-undang menyatakan bahwa organisasi dapat menentukan persyaratan 'wakif' sesuai anggaran dasar organisasi yang besangkutan. Akan tetapi, apabila wakif tersebut berupa badan hukum, maka persyaratan waqif menurut undang-undang diserahkan kepada ketentuan badan hukum. 
Media Komunikasi dan Informasi Hukum dan Masyarakat

2) Syarat Maukuf bih (Benda yang merupakan kesepakatan para ulama. diwakafkan):

Menjadikan hukum Islam sesuai dalam berbagai

a. harus berupa benda yang mempunyai keadaan menunjukkan hukum ini layak dijadikan nilai/berguna, benda tetap atau benda bergerak yang dibenarkan untuk diwakafkan;

b. harus diketahui ketika diakadkan;

c. merupakan harta yang telah menjadi milik tetap si wakif ketika diakadkan. Sedangkan merujuk UU No. 41/2004, barang yang diwakafkan diberikan ketentuan' yang bersifat umum, dimana harta benda objek waqaf itu harus dimiliki dan dikuasai wakif secara sah, sedangkan jenis dan macam barang waqaf disebutkan secara terbatas (limitatif).

3) Syarat Maukuf alaihi, merujuk pada pemanfaatan harta zakat sesuai pada batas-batas yang dibolehkan secara syariat.

4) Syarat sighat akad, merupakan seluruh ucapan, tulisan atau isyarat dari individu yang berakad guna menyatakan keingingan/kehendak dan menjelaskan apa yang dikehendakinya.

Rukun dan syarat wakaf ini tidak bersifat mutlak dan bukan tidak bisa ditambah, mengingat urgensi dan bentuk perbuatan hukum wakaf semakin bertambah sesuai dengan perkambangan zaman. Hal ini mendorong berbagai pengkajian demi menemukan formulasi perbuatan hukum wakaf yang lebih baik lagi.

\section{B. Penerapan Wakaf Sebagai Suatu Perbuatan Hukum Dalam Perspektif Kemaslahatan Dan Akuntabilitas}

Hukum Islam sesuai dengan perubahan waktu, tempat dan keadaan. Term ini sangat dikenal dalam metodologi hukum Islam karena

Kemaslahatan sebagai suatu keniscayaan yang harus dicapai dalam berbagai hal, selama tidak bertentangan dengan hukum Islam. Di sisi lain, maslahah dan mafsadah kerap dimaksudkan dengan baik dan buruk, manfaat dan mudarat, bagus dan jelek. Karena, semua mashlahah itu baik sedangkan mafsadah itu semuanya buruk, berbahaya dan tidak baik bagi manusia. Sedangkan menurut al-Ghazali (w. $505 \mathrm{H}$ ), maslahah merujuk pada upaya meraih manfaat dan menolak mudarat. Selanjutnya al-Ghazali menegaskan maslahah upaya menjaga maqasid as-syari'ah. Maqasid as-syari'ah terdiri dari lima agama, jiwa, akal, nasab, dan harta. Dengan demikian mashlahah merujuk pada setiap perkara yang ada salah satu unsur dari maqashid as-syari'ah. Sebaliknya, jika tidak ada salah satu unsur dari maqashid as-syari'ah, maka ia merupakan perkara mafsadah, dan mencegahnya adalah mashlahah.

Terkait kemaslahatan dalam perbuatan wakaf, harta benda yang menjadi objek wakaf harus benar-benar dapat dijaga dan dipelihara dengan baik guna mewujudkan kebaikan bagi senua pihak. Harta pewakif harus benar-benar dijaga dan dikelola dengan baik dan menjunjung tinggi nilai-nilai kejujuran dan transparansi.

Tidak diperbolehkan untuk merubah aset pokok wakaf meskipun untuk yang lebih baik kecuali berdasarkan syariat dari seorang waqif yang memperbolehkan perubahan kepada yang terbaik sesuai maslahat. Dalam pendapat lain menurut Subki, boleh merubah wakaf dengan 3 syarat, pertama, tidak sampai merubah status wakaf. Kedua menambah 
Media Komunikasi dan Informasi Hukum dan Masyarakat

banyaknya pemasukan dan ketiga tidak menghilangkan atau merubah posisi struktur mauquf. ${ }^{10}$

Dalam perspektif akuntabilitas, semua kegiatan pada dasarnya harus dilakukan pencatatan dan pengawasan yang baik, sehingga menghasilkan hasil yang baik pula. Demikian juga halnya dalam kegiatan wakaf. Sangat diperlukan ada terpenuhinya sisi akuntabilitas mengingat wakaf ini merupakan pengelolaan terhadap harta kaum muslim.

Sebagaimana yang telah dikemukakan pada pemaparan sebelumnya, akuntabilitas dapat merupakan suatu kewajiban membuat laporan dan bertanggung jawab atas keberhasilan ataupun kegagalan pelaksanaan misi organisasi dalam meraih tujuan dengan menggunakan media pertanggungjawaban secara berkala.

Oleh sebab itu para nazir wakaf juga dituntut untuk memberikan laporan pertanggungjawaban atas berbagai kegiatan dalam pengelolaan wakaf yang dilakukannya, khususnya kepada Badan Wakaf Indonesia. Namun realitanya masih banyak ditemukan sekarang berbagai lembaga wakaf yang tidak melaporkan pengelolaan wakaf yang dilakukannya, sehingga pada akhirnya bisa berakibat kepada kelemahan dalam pengeloaan wakaf tersebut. Keterbukaan di zaman sekarang ini juga sangat dibutuhkan, khususnya terkait dengan pengelolaan harta umat.

Dalam konteks negara Indonesia, perbuatan hukum wakaf sudah dilaksanakan oleh masyarakat Muslim Indonesia sejak sebelum merdeka. Oleh karena itu pihak pemerintah telah menetapkan Undang-undang khusus yang mengatur tentang perwakafan di

${ }^{10}$ Syihabudin Al-Qalyubi, Hasyiyah al-Qalyubi, Jld. 3. Daru Ihya al-Kutub Al-Arabiyah, t.th, hal. 108
Indonesia, yaitu Undang-undang nomor 41 tahun 2004 tentang Wakaf. Untuk melengkapi Undang-undang tersebut, pemerintah juga telah menetapkan Peraturan Pemerintah nomor 42 tahun 2006 tentang Pelaksanaan UndangUndang Nomor 41 Tahun 2004.

Dalam UU Nomor 41 Tahun 2004, mengenai rukun dan syarat wakaf tidak dirinci sebagaimana di dalam fiqih. Dalam UU tersebut hanya ditegaskan bahwa: "Wakaf sah apabila dilaksanakan menurut syariah". Berdasarkan hal ini, UU tetap memberikan kewenangan oleh syariah Islam untuk menilai keabsahan pelaksanaan wakaf, termasuk dalam hal syarat dan rukun wakaf ini.

Dalam perwakafan, sang pengelola wakaf atau yang lebih dikenal dengan istilah nazhir sangat membutuhkan manajemen yang baik dalam menjalankan tugasnya. Manajemen ini digunakan untuk mengatur kegiatan pengelolaan wakaf, menghimpun wakaf dan menjaga hubungan baik antara nazhir, pewaqaf dan masyarakat. Di samping itu, manajemen sangat dibutuhkan sebagai bagian dari usaha agar kegiatan pengelolaan wakaf dapat berjalan secara efektif dan efisien. Agar manajemen wakaf yang dilakukan mengarah kepada kegiatan wakaf secara efektif dan efisien, manajemen perlu mendapat perhatian penting dalam pengelolaan wakaf.

Mengenai konsep manajemen wakaf, Ahmad Shabab ${ }^{11}$ mengemukakan bahwa unsur utama dari manajemen adalah perencanaan (altakhtih), pengorganisasian (al-tanzhim), kepemimpinan (al-qiyadah) dan pengawasan (al-riqabah).

Bagian pengawasan (al-riqabah) atau yang disebut dengan controling merupakan

${ }^{11}$ Ahmad. Shabab, Mabadiu al-ldarah, Juz 1, Jami'ah Malik Abdul Azis t.th, Makkah, hal. 11 
Media Komunikasi dan Informasi Hukum dan Masyarakat

proses untuk memastikan bahwa aktifitas sebenarnya sesuai dengan yang direncanakan. Pengawasan merupakan proses yang dilakukan untuk memastikan seluruh rangkaian kegiatan yang telah direncanakan, diorganisasikan dan diimplementasikan agar dapat berjalan sesuai target yang diharapkan, sekalipun terjadi berbagai perubahan. Pengawasan atau pengendalian merupakan fungsi terakhir dari proses manajemen. Fungsi ini merupakan aktivitas manajemen yang terkait dengan fungsi manajemen lainnya, terutama perencanaan, karena sistem pengawasan atau pengendalian harus terlebih dahulu ada dalam perencanaan. Pelaksanaan dari rencana bisa berjalan dengan baik jika dikendalikan dengan cara yang baik. Oleh karena itu, sangat tepat bila dikatakan bahwa pengawasan atau pengendalian sangat menentukan pelaksanaan baik atau tidaknya proses manajemen. ${ }^{12}$

Salah satu tujuan hukum Islam adalah menjaga harta. Dimana harta umat Islam harus benar-benar dijaga dan dikelola dengan baik agar peruntukannya sesuai dengan ajaran Islam dan tidak menyimpang dari rel agama. Untuk menjaga kemaslahatan umum khususnya menjaga aset wakaf yang nota bene harta umat serta mencegah pertikaian yang muncul dari penarikan harta benda wakaf yang telah diberikan misalnya atau hal-hal lainnya, maka dirasa perlu untuk memperkuat sisi akuntabilitas dalam pengelolaan wakaf yang dimulai bentuk pencatatan ikrar wakaf di lembaga resmi milik pemerintah yang dalam hal ini diakomodir oleh Kementerian Agama RI. Disamping itu, dalam pengelolaannya juga perlu untuk disampikan ke publik secara berkala, untuk menghindari kesalahan atau penyimpangan dalam pengelolaannya.

\footnotetext{
${ }^{12}$ Rozalinda, Op.Cit, hal. 84
}

Kewajiban melakukan akta ikrar wakaf dan pelaporan ke publik secara berkala dapat dijadikan bagian syarat yang harus dilaksanakan bagi setiap pengelola wakaf termasuk pemberi wakafnya. Disamping itu, pelaporan secara berkala terhadap pengelolaan wakaf juga sangat urgen, mengingat harta wakaf merupakan harta umat dan umat juga berhak mengetahui hasil atau cara pengelolaannya.

Terlebih lagi pada jenis wakaf khairy yang banyak dirasakan manfaatnya oleh masyarakat. Negara dalam hal ini Kementerian Agama Rl harus hadir memayungi praktik wakaf, sehingga dapat terjaga kemaslahatannya dan terhindar dari berbagai hal yang negatif.

Terlebih akuntabilitas pada wakaf tunai, sangat perlu dilakukan, mengingat banyak masyarakat juga belum mengerti wakaf tunai disertai dengan berbagai kebijakan terkait akibat dari pelaksanaan wakaf tunai tersebut. Dalam hal ini, pencatatan wakaf tunai harus benarbenar bisa diwujudkan dan diseriusi oleh berbagai pihak.

Dalam rangka usaha penertiban administrasi perwakafan tanah, maka perlu diadakan pencatatan dan pengadministrasian tanah wakaf. Upaya tertib administrasi perwakafan tertuang dalam pembuatan akta ikrar wakaf (AIW), baik harta benda wakaf berupa tanah maupun benda lainnya. Hal ini telah diatur dalam Peraturan Pemerintah No. 28 Tahun 1977. Dalam Peraturan Menteri Agama No. 1 Tahun 1978 tentang Pelaksanaan Peraturan Pemerintah No. 28 Tahun 1977 Tentang Perwakafan tanah milik telah diatar bahwa Kepala Kantor Urusan Agama (KUA) Kecamatan ditunjuk sebagai Pejabat Pembuat Akta Ikrar Wakaf dan administrasi perwakafan diselenggarakan di Kantor Urusan Agama 
Media Komunikasi dan Informasi Hukum dan Masyarakat

Kecamatan. Kemudian pemerintah menertibkan administrasi perwakafan melalui UU No. 41 Tahun 2004 tentang Wakaf. Peraturan Pemerintah No. 42 Tahun 2006 tentang Pelaksanaan Undang-Undang No. 41 Tahun 2004 tentang wakaf. Pencatatan dan pengabdminitrasian harta wakaf sudah dilakukan ketika waqif mengucapkan ikrar wakafnya di hadapan PPAIW. Kemudian PPIW menetapkan akta ikrar wakaf. Lalu PPAIW mengeluarkan SK Pengesahan nazhir harta wakaf tertentu.

Pada pasal 29 UU No. 41 Tahun 2004 tentang wakaf dinyatakan bahwa wakaf benda bergerak berupa uang dilaksanakan oleh waqif dengan pernyataan kehendak waqif yang dilakukan secara tertulis. Semetara itu, ikrar wakaf dilaksanakan oleh waqif kepada nazhir di hadapan pejabat Lembaga Keuangan Syariah Penerima Wakaf Uang (LKS-PWU) atau notaris yang ditunjuk sebagai PPAIW dengan disaksikan oleh 2 (dua) orang saksi. Ikrar wakaf dilakukan setelah waqif menyetorkan wakaf uang kepada LKS-PWU. Pejabat LKS-PWU atau notaris menerbitkan AIW yang memuat sekurang-kurangnya data; nama dan identitas waqif, nama dan identitas nazir, nama dan identitas saksi, jumlah nominal, asal usul uang; peruntukan dan jangka waktu wakaf. Bentuk dan spesifikasi formulir AIW ditetapkan dengan keputusan Direktur Jenderal. (PMA No. 4 Tahun 2009). Adapun yang bertindak sebagai PPAIW untuk wakaf uang adalah LKS PWU yang ditunjuk Menteri Agama. (PP No. 42 Tahun 2006). ${ }^{13}$

13 Sebagaimana yang dikemukakan oleh Rozalinda, ada sebanyak 8 (delapan) Bank Syariah yang ditunjuk oleh Menteri Agama sebagai Lembaga Keuangan Syariah Penerima Wakaf Uang. Yaitu PT BNI Tbk Divisi Syariah dengan Keputusan Menteri Agama RI No. 92 Tahun 2008, PT. Bank Muamalat Indonesia Tbk dengan Keputusan Menteri Agama RI No. 93 Tahun 2008, PT Bank DKI Jakarta
Merujuk kepada paparan dimensi akuntabilitas yang telah dikemukakan sebelumnya (akuntabilitas hukum dan kejujuran/accuntability for probity and legality), aturan perundang-undangan ini memperkuat urgensi pencatatan dalam pelaksanaan wakaf. Karena dengan adanya pencatatan ini memperkuat pelaksanaan wakaf dan merupakan bagian dari penghindaran diri dari penyimpangan atau penyelewangan yang bisa saja terjadi di masa yang akan datang.

Selanjutnya, akuntabilitas manajerial. Dimana, akuntabilitas manajerial yang bisa juga dimaknai dengan akuntabilitas kinerja (performance accountability) yang merupakan pertanggungjawaban untuk melakukan pengelolaan organisasi secara efektif dan efisien. Dalam pengelolaan wakaf juga dibutuhan manajemen yang baik sebagai bentuk pertanggungjawaban untuk mengelola organisasi lembaga wakaf. Dengan baik manajemen yang dilakukan, maka akan muncul banya trust dari masyarakat.

Dengan penertiban prosedur dan pengadministrasian perkawafan tanah melalui manajemen yang baik, maka diharapkan administrasi perwakafan tanah dapat dikelola dengan baik dan tertib. Dengan demikian, semua tanah wakaf dapat tercatat oleh negara dan juga dapat dikontrol untuk meminimalisir kesalahan atau penyimpangan dalam pengelolaan wakaf.

Kemudian Akuntabilitas program. Akuntabilitas program juga berarti bahwa program-program organisasi hendaknya merupakan program yang bermutu dan

dengan Keputusan Menteri Agama RI No. 94 Tahun 2008, PT Bank Syariah Mandiri dengan Keputusan Menteri Agama No. 95 Tahun 2008, PT Bank Mega Syariah Indonesia dengan Keputusan Menteri Agama RI No. 96: Bank Bukopin, BTN dan BPD Yogyakarta. LihatL Rozalinda, Manajemen Wakaf Produktif, h. 67 
Media Komunikasi dan Informasi Hukum dan Masyarakat

mendukung strategi dalam pencapaian visi, misi dan tujuan organisasi. Lembaga publik harus mempertanggungjawabkan program yang telah dibuat sampai pada pelaksanaan program. Dengan demikian lembaga pengelola wakaf dituntut untuk menjalankan program, strategi dan visi misi yang dibuat.

Akuntabilitas kebijakan. Lembagalembaga publik (dalam hal ini lembaga pengelola wakaf) hendaknya dapat mempertanggung jawabkan kebijakan yang telah ditetapkan dengan mempertimbangkan dampak dimasa depan. Pengembangan wakaf yang dilakukan pengelola wakaf harus disertai pertanggungjawaban dalam bentuk laporan kepada masyarkaat mengenai pengelolaan wakaf yang dilakukan pengelola wakaf.

Terakhir, Akuntabilitas finansial merupakan pertanggungjawaban lembaga lembaga publik untuk menggunakan dana publik (public money) secara ekonomis, efisien dan efektif, tidak ada pemborosan dan kebocoran dana, serta korupsi. Dengan demikian lembaga wakaf harus benar-benar mempergunakan harta wakaf sesuai dengan peruntukannya dengan tidak melakukan penyimpangan atau penyalahgunaan pemanfaatan harta wakaf.

Dari kelima dimensi akuntabilitas ini, tampaknya mengenai pencatatan harta wakaf merupakan sesuatu yang sangat urgen dilakukan. Agar pelaksanaan wakaf dari sejak dini dilakukan dengan baik dengan penuh tanggung jawab. Di samping itu selanjutnya, juga perlu mewujudkan akuntabilitas baik dari sisi akuntabilitas manajerial, program, kebijakan dan finansial.

Melihat urgensi pencatatan wakaf ini dalam dimensi akuntabilitas pertama diatas, maka demikian halnya dalam perspektif maslahat dapat dijadikan pencatatan tersebut sebagai suatu kewajiban yang harus dilakukan setiap pewakif (pelaku wakaf). Demikian juga halnya dengan manajerial dan pelaporan pengelolaan wakaf kepada publik secara berkala sangat penting dilakukan untuk menjaga kemaslahatan harta wakaf dan bagian dari akuntabiitas pengelolaan wakaf.

Perbuatan mukallaf yang berhubungan dengan hukum syariat itu adakalanya bertujuan untuk mewujudkan kemashlahatan umum dan adakalanya untuk mewujudkan kemashlahatan khusus, demikian juga dalam perbuatan hukum wakaf ini. Apabila tujuannya kemashlahatan umat secara umum, maka perbuatan tersebut adalah hak Allah, dan apabila tujuannya kemashlahatan khusus maka perbutan tersebut adalah hak hamba/manusia. Sebagai pengejawantahan bagian adari kemaslahatan, maka pencatatan dalam perbuatan hukum wakaf sangat urgen diterapkan, sehingga berdasarkan sisi akuntabilitas dan kemaslahatan pencatatan merupakan perbuatan yang termasuk bagian inti dari suatu perbuatan hukum.

Bahkan dalam bentuk yang sederhana, dalam pemberian wakaf Alquran misalnya di masjid harus juga dilakukan pencatatan, agar mushaf-mushaf Alquran yang ada di dalam masjid dapat terdapat dan mempermudah bagi nazhir untuk memeliharanya. Meskipun kalau dilihat

Rekonstruksi hukum wakaf dalam perspektif hukum islam berdasarkan kemaslahatan dan akuntabilitas mensyaratkan bahwa hukum perkawafan harus diperbaruhi, Wakif, yakni individu yang menyerahkan hartanya sebagai waqaf, Mauquf merupakan harta yang diserahkan sebagai waqaf, Mauquf 'alaihi, merupakan niat atau tujuan/ individu yang bertanggungjawab dalam mengelola harta 
Media Komunikasi dan Informasi Hukum dan Masyarakat

waqaf, dan Sighat adalah sebuah pernyataan dari waqif bahwa waqif bahwa hartanya telah diwaqafkan serta pencatatan wakaf.

Di samping itu pelaporan harta wakaf juga termasuk bagian dari kewajiban yang harus dilakukan oleh pengelola wakaf kepada masyarakat, guna menjadikan hukuman antara pihak masyarakat (baca: umat) dan pengelola wakaf dapat berjalan baik dan pengelola bisa mendapatkan trust dari umat, sehingga bisa berakibat kepada penambahan harta wakaf itu sendiri.

Badan Wakaf Indonesia (BWI) sebagai lembaga wakaf Indonesia harus menjadi garda terdepan untuk mengawasi berbagai lembaga atau yayasan wakaf yang ada di Indonesia. Semua yayasan wakaf berkewajiban untuk melaporkan kegiatan pengelolaan wakaf yang dilakukan kepada BWI, sedangkan bagi lembaga wakaf produktif diberikan kewajiban tambahan yaitu melaporkan kegiatan operasional lembaga wakaf ke publik untu menjadi kemaslahatan harta wakaf dan juga akuntabilitas dihadapan publik.

\section{Penutup}

\section{A. Kesimpulan}

1. Wakaf merupakan salah satu perbuatan hukum, oleh karena itu dalam pelaksanaannya harus diperhatikan mengenai syarat dan rukunnya. Dalam istilah fikih, perbuatan mukallaf disebut dengan mahkim fih.

2. Penerapan perbuatan hukum wakaf sebagai suatu perbuatan hukum dalam perspektif kemaslahatan dan akuntabilitas dapat diwujudkan dengan melakukan pencatatan wakaf hingga pelaporan perkembangan pengelolaan wakaf kepada lembaga Badan Wakaf Indonesia (BWI) atau langsung kepada publik. Merujuk kepada perspektif kemaslahatan dan akuntabilitas, kedudukan pencatatan wakaf di awal akad layak disamakan dengan rukun lainnya. Disamping itu pelaporan pengelolaan wakaf juga wajib disampaikan lembaga Badan Wakaf Indonesia (BWI) atau langsung kepada publik.

\section{B. Saran}

Saran yang dapat diberikan dalam penelitian ini adalah:

1. Pemerintah dalam hal ini Kementerian Agama harus memberikan fokus dalam edukasi dan sosialisasi perbuatan hukum wakaf sesuai rukun dan syarat yang ditetapkan baik oleh fikih klasik maupun aturan perundang-undangan.

2. Pengelola wakaf harus ikut serta dalam melakukan edukasi dan sosialisasi kepada masyarakat tentang pengelolaan wakaf.Masyarakat khususnya umat Islam harus senantiasa menggalakkan perbuatan hukum wakaf sembari memperhatikan halinwal terkait praktik pelaksanaan perbuatan hukum wakaf yang sesuai dengan syariah dan aturan perundang-undangan. 
Media Komunikasi dan Informasi Hukum dan Masyarakat

\section{DAFTAR PUSTAKA}

\section{A. Buku}

Al-Jauziyyah, Ibn al-Qayyim. 1996. I'lam alMuwaqqi'in. Beirut, Dar al-Kutub al'Ilmiyyah. Jld. 3, Beirut, 1996.

Al-Qalyubi, Syihabudin. t.t. Hasyiyah al-Qalyubi. Jld. 3. Daru Ihya al-Kutub Al-Arabiyah

Al-Syatiby. tth. al-Muawafaqat fi Ushul alAhkam. Mustafa Muhammad. Jld. 2, Kairo.

Al-Thayyar, Abdullah. Ensiklopedi Figh Muamalah, Maktabah al-Hanif, Yogyakarta, 2009.

Auda, Jasser, Reformasi Hukum Islam Berdasarkan Filsafat Makasid Syariah, trjm. Rosidin dan Ali Abd Mun'im. Medan, Fak. Syariah IAIN-SU, 2014.

Binhadi, D, Pedoman Umum Good Corporate Governance Indonesia. Jakarta, 2006.

Budiman, A. A, Akuntabilitas Lembaga Pendikan Waqaf. Walisongo: Jurnal Penelitian Sosial Keagamaan, 2011.

Djamil, Fathurrahman. 1999. Filsafat Hukum Islam. Logos Wacana IImu, Ciputat, 1999.

Hanafi, Pengantar dan sejarah hukum Islam, Pustaka Bulan Bintang, Jakarta, 1970.

Haq, Faisal, Hukum Perwakafan di Indonesia. RajaGrafindo Persada, Jakarta, 2017.

Hikmah, Fiqih, Akik Pusaka, Sragen, 2014.

Khalaf, Wahab, IImu Ushul Fiqh, Dar al-Kutub al-Islamiyah, Jakarta, 2010.

Khallaf, Wahhab, Kaidah-Kaidah Hukum Islam, PT. RajaGrafindo Persada, Jakarta, 1996.

Manan, Abdul, Reformasi Hukum Islam. RajaGrafindo, Jakarta, 1996.

Mardani, Aspek Hukum Lembaga Keuangan Syariah Di Indonesia, Prenamedia Group, Jakarta, 2015.

Mardiasmo, Akuntabilitas Sektor Publik (IV), C.V Andi Offset. Yogyakarta, 2009.
Nasution, Lahmuddin, Pembaharuan Hukum Islam dalam Mazhab Syafi'i, PT. Remaja Rosdakarya, Bandung, 2001.

Nurlinda, Akuntabilitas Pengelolaan Keuangan Desa. Jurnal Riset Akuntansi \& Keuangan, 2018.

Prihatini, Farida, Hukum Islam Zakat dan Wakaf, Papas Sinar Kinanti dan Badan Penerbit Fakultas Hukum Universitas Indonesia (UI), Jakarta, 2005.

Rasul, Syahruddin, Pengintegrasian Sistem Akuntabilitas Kinerja dan Anggaran.Jakarta: Detail Rekod, 2002.

Rozalinda, Manajemen Wakaf Produktif. RajaGrafindo Persada, 2016.

Shabab, Ahmad. t.th. Mabadiu al-ldarah. Makkah: Jami'ah Malik Abdul Azis. Juz 1.

Shomad, Abdul, Hukum Islam Penormaan Prinsip Syariah Dalam Hukum Islam Indonesia, Kencana, Jakarta, 2010.

Syafe"i, Rachmat, IImu Ushul Fiqih.Pustaka Setia, Bandung.

Syarifuddin, Amir, Ushul Fiqh, Logos Wacana IImu, Jakarta, 2011.

Zuhaily, Wahbah, Ushul Fiqh al-Islamy. Damaskus: Darul Fikr. Jld. I, 2004.

\section{B. Peraturan Perundang-Undangan}

Undang-Undang No. 41 Tahun 2004 tentang Wakaf.

Peraturan Pemerintah No. 42 Tahun 2006 tentang Pelaksanaan Undang-Undang No. 41 Tahun 2004 tentang wakaf

Kompilasi Hukum Islam. 